\title{
Evaluation of Factors Affecting Sexual Activity and Sexuality- Related Quality of Life in Different Stages of Pregnancy
}

\author{
Gebeliğin Değişik Dönemlerinde Cinsel Aktiviteyi ve Cinselliğe Bağlı Hayat Kalitesini \\ Etkileyen Faktörlerin Değerlendirilmesi
}

\author{
(1) Evren Çavuş, (D) Fatma Beyazıt \\ Çanakkale Onsekiz Mart University Faculty of Medicine, Department of Obstetrics and Gynecology, Çanakkale, Turkey
}

\begin{abstract}
Introduction: Pregnancy is a special period in which physiological and psychological changes are observed in the body. Sexuality-related problems exhibit significant changes during pregnancy. In this study, we aimed to determine the distribution of changes in sexual behavior during pregnancy according to the trimesters and to determine the effects of these dysfunctions on quality of life.

Methods: This study was performed in order to investigate the sexual life of pregnant women during pregnancy and the factors that affect sexual function in women followed up in the outpatient of clinic Çanakkale Onsekiz Mart University, Department of Obstetrics and Gynecology between June 2017 and July 2017. The study included 300 pregnant women. Demographic data form and two questionnaires were applied to pregnant women. One of the questionnaires was aimed to determine the sexual function of pregnant women [Female Sexual Function Index (FSFI)] and the other was aimed to determine the quality of sexual life in pregnancy [Sexual Quality of Life-Female (SQoL-F) questionnaire].

Results: SQoL-F scores were found to be higher in the second trimester than in the first trimester $(p=0.005)$. There was a statistically significant difference between the trimesters in terms of total FSFI scores and the highest score was in the second trimester $(p=0.048)$. Subscales of FSFI scores were also evaluated and lubrication score was higher in the second trimester compared to other trimesters $(p=0.009)$. Sexual success score in the second trimester was higher than in the first trimester $(p=0.014)$.

Conclusion: In this study, we observed a significant decrease in sexual functions during pregnancy and fluctuations in sexual function between trimesters that are comparable with literature data. It is very important for health professionals to provide guidance in solving current problems by providing appropriate counseling services to pregnant women who express that they have problems during sexual intercourse.
\end{abstract}

Keywords: Pregnancy, quality of life, sexual dysfunction, sexuality öz

Amaç: Gebelik, vücutta fizyolojik ve psikolojik değișikliklerin görüldüğü özel bir süreçtir. Gebelik süresince cinsellikle ilgili yaşanan sorunlar gebelik trimesterlerine bağlı değișiklikler göstermektedir. Bu çalışmada gebelik süresince yaşanan cinsel ișlevdeki değișimlerin trimesterlere göre dağılımını ve bu fonksiyon bozukluklarının hayat kalitesi üzerine etkilerini belirlemeyi amaçladık.

Yöntemler: Bu çalıșma, Çanakkale Onsekiz Mart Üniversitesi Tıp Fakültesi, Kadın Hastalıkları ve Doğum Anabilim Dalı gebe polikliniğine Haziran 2017 ve Temmuz 2017 tarihleri arasında başvuran gebelerin cinsel yaşamlarının ve bunu etkileyen etmenlerin incelenmesi amacıyla yapılmıștır. Çalıșmaya 300 gebe kadın dahil edilmiştir. Gebelere demografik bilgilerinin belirlendiği bir form ve 2 anket formu uygulanmıștır. Anket formlarından biri gebelikte cinsel fonksiyonların düzeyini [Female Sexual Function Index (FSFI)] belirlemek, diğeri ise gebelikteki cinsel yaşamın kalitesini [(Cinsel Yaşam Kalite ölçeği-Kadın (CYKö-K)] belirlemeye yönelik idi.

Bulgular: CYKÖ skoru birinci trimester ile kıyaslandığında ikinci trimesterde daha yüksek idi $(p=0.005)$. Trimesterler arasında total FSFI skorları açısından istatistiksel olarak anlamlı fark mevcuttu ve aynı zamanda en yüksek skor ikinci trimesterde idi $(p=0,048)$. FSFI alt başlıkları kendi içlerinde değerlendirildiklerinde lubrikasyon skoru ikinci trimesterde diğer trimesterler ile kıyaslandığında daha yüksek idi $(p=0,009)$. Cinsel başarı ikinci trimester skoru birinci trimester skorundan daha yüksek idi $(p=0,014)$.

Sonuç: Bu çalıșmada gebelikteki cinsel fonksiyonlardaki düşüş ve özellikle de trimesterler arası cinsel fonksiyonlardaki dalgalanma genel literatür verileriyle uyumlu olarak saptandı. Sağlık çalışanlarının cinsel ilișki sırasında sorun yaşadığını ifade eden gebelere uygun danışmanlık hizmeti vererek mevcut sorunların çözümünde rehberlik sağlamaları son derece önemlidir.

Anahtar Kelimeler: Gebelik, hayat kalitesi, cinsel ișlev bozukluğu, cinsellik 


\section{Introduction}

Sexual life is an important part of an individual's health and quality of life $(1,2)$. Sexual life includes gender, sexual identities and roles, sexual orientations, eroticism, pleasure, physical closeness and continuity of generation, and is an essential element of human life (3). Human sexuality and sexual quality of life (SQoL) are influenced by many factors. Race, ethnicity, social status, marital status, family and social support groups, vocational and educational levels are among the main factors affecting sexuality. Factors such as diseases, medical and surgical interventions, infertility, gynecological symptoms, gynecological cancers, changes in family life and domestic violence are other factors that affect the individual's sexual health and quality (3-5). Physiological life events such as menstrual cycle, pregnancy, birth, breastfeeding, menopause during a woman's life and old age can also affect the SQoL $(3,6)$. Conditions such as previous and current diseases, previous pregnancies and births, and gestational week may affect sexual life of a woman during pregnancy $(6,7)$. At the same time, emotional changes and psychological repercussions of physiological changes are other factors that influence sexual life $(8,9)$.

Pregnancy is an important process in which physiological and psychological changes occur. Physiological and psychological changes that occur during pregnancy can affect the sexual life negatively. Sexuality, which is an essential element of human life, is negatively affected by pregnancy and this will negatively affect the quality of life of the individual $(3,5,6)$.

In our study, we aimed to determine the factors affecting the sexual function of pregnant women at different stages of pregnancy (all three trimesters) and the effect of these factors on the SQoL in pregnant women.

\section{Methods}

This study was performed in accordance with the Declaration of Helsinki and Çanakkale Onsekiz Mart University Clinical Research Ethics Committee approved this study (decision no: 2017/11, date: 07.06.2017). Following approval, a cross-sectional study was performed on 300 pregnant women who admitted to the department of obstetrics and gynecology between June 2017 and July 2017, and who signed written informed consent.

Convenience sampling, a type of non-probability sampling, was used for sampling and was set as 100 pregnant women for every 3 trimesters who met inclusion criteria and who were willing to participate in the study. The inclusion criteria were determined as follows: being able to establish healthy communication, absence of risk factors (abortion risk, infection, third trimester bleeding, premature rupture of membranes, premature birth risk) during pregnancy, no restriction on the sexual life with the recommendation of a physician and being over 18 years of age. Pregnant women who did not agree to participate in the study, who were not sexually active, who still did not live with the same partner and who were younger than 18 years of age were excluded from the study.

\section{Evaluations}

The gestational ages of the pregnant women included in the study were determined according to the last menstrual period and were confirmed by ultrasound. The first trimester was determined as 4-14 weeks, the second trimester as 14-28 weeks and the third trimester as 28-42 weeks. Pregnant women were asked to fill out a data form for demographic information. In addition, 2 more questionnaires were applied. One of the questionnaires was to identify the sexual dysfunction in pregnancy (Female Sexual Function Index: FSFI). Sexual function scores of pregnant women were calculated with this index. SQoL-Female (F) was used to determine whether there was a difference between the SQoL before and after conception. Demographic data form was aimed to gather information on age, employment status, education level, type of marriage (arranged-love) and place of residence.

\section{Female Sexual Function Index Questionnaire}

The FSFI scale consists of 6 sub-headings including 19 questions asked to identify sexual functions. First and second questions are about sexual desire, 3-4-5- $6^{\text {th }}$ about sexual arousal, $7-8-9-10^{\text {th }}$ about lubrication, $11-12-13^{\text {th }}$ about orgasm, $14-15-16^{\text {th }}$ about satisfaction and $17-18-19^{\text {th }}$ about pain. The scores from the answers to these questions were used to determine the sexual function of the patients by having a score between 0 and 40 . The reliability and validity study of the Turkish version of this scale, which was developed by Rosen et al. (10), was done by Aygin and Eti Aslan (11).

\section{Sexual Quality of Life-Female Questionnaire Form}

SQoL scale during pregnancy is a self-assessed, easy to use questionnaire consisting of 18 questions, each with a 6 -point Likert scale ( $1=$ completely agree, $2=$ moderately agree, $3=$ slightly agree, $4=$ slightly disagree, $5=$ moderately disagree, $6=$ completely disagree). Each item is expected to be answered by the patient regarding the sex life in the last four weeks. The score range of this scale is 18-108. The scores of items 1, 5, 9, 13 and 18 are reversed before the total score is calculated. Raw scores must be transformed onto a standardized scale of 0 to 100 using the following formula: "Scale score= the sum of the component items (minus) the lowest possible score * 100 possible raw score range". The answers to the questions are collected as points and these points are used to calculate the SQoL by converting to percentage values. The higher the score, the better the SQoL. The validity and reliability study of the Turkish version of SQoL-F was published by Tuğut and Gölbașı (5) in 2010.

\section{Statistical Analysis}

All data were analyzed using SPSS version 20 (Chicago, IL, USA) program. The data were presented as median (minimum-maximum) or mean \pm standard deviation depending on the normality of data distribution. Mann-Whitney $U$ test was used for pairwise comparisons. $P$ values $<0.05$ were considered significant. Kruskal-Wallis test was used to compare FSFI scores between three trimesters. Pairwise comparison of three trimesters was performed using Mann-Whitney $U$ test following Bonferroni correction to make comparisons regarding lubrication, sexual satisfaction, total FSFI score and SQoL-F score before and after conception, which were significantly different between the FSFI scores. Pairwise comparisons of four sub-headings, which have a difference between them in the Kruskal-Wallis test, were performed between the three trimesters. 


\section{Results}

A total of 300 pregnant women were included in the study and the mean age of these pregnant women was $28.61 \pm 5.6$ years. The mean age of pregnant women according to trimesters is shown in Table 1. Regarding mean gravida, mean gravida was $1.90 \pm 1.1$ in the first trimester group, $1.94 \pm 1.1$ in the second trimester group and $1.87 \pm 1.0$ in the third trimester group. The mean parity was $0.68 \pm 0.79$ in the first trimester group, $0.71 \pm 0.87$ in the second trimester group and $0.66 \pm 0.75$ in the third trimester group. Other demographic data of pregnant women, including education level and place of residence, are detailed in Table 1.

Regarding total FSFI scores, median total FSFI was 22.8 (20.0-25.1) in the first trimester group, $23.6(21.7-26.1)$ in the second trimester group and $22.0(16.1-25.5)$ in the third trimester group. There was no significant difference between total FSFI scores of pregnant women in all 3 groups (Figure 1). Regarding FSFI subscales, median FSFI sexual desire scores were not statistically significant $(p=0.51)$. When FSFI subscales were evaluated in terms of trimesters, it was found that there was a statistically significant difference between the trimesters only in the lubrication and sexual satisfaction subscales ( $p=0.039$ and $p=0.012$, respectively). The relationship between other subscales and trimesters is given in Table 2.

Pregnant women in all 3 trimesters were evaluated before and after pregnancy in terms of SQoL-F scores. The median SQoL-F values before pregnancy were 55.5 (46.6-87.7) in the first trimester, 78.2 (57.7-93.3) in the second trimester and 74.9 (51.1-94.4) in the third trimester. The median SQoL-F values after pregnancy were 55.5 (44.4-80.0) in the first trimester, 64.4 (52.2-88.8) in the second trimester and 64.9 (57.7-92.2) in the third trimester (Table 2).

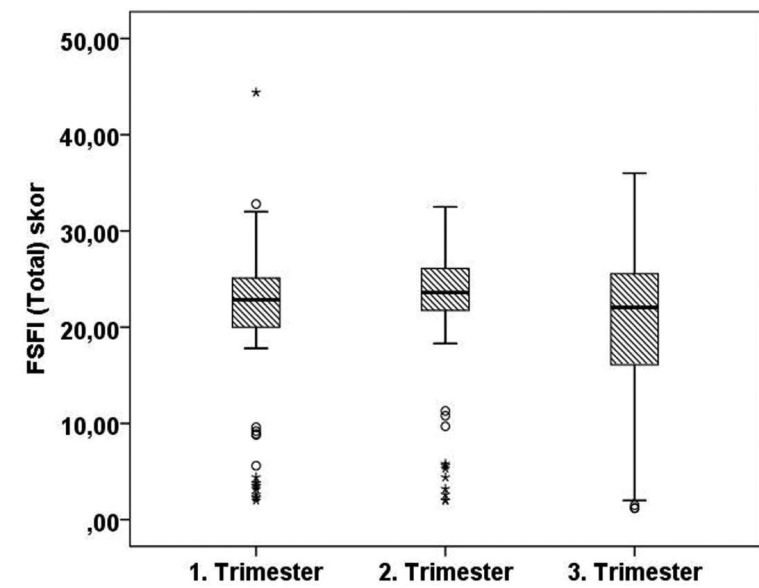

Figure 1. Mean FSFI total score of pregnant women according to trimesters FSFI: Female Sexual Function Index

\section{Table 1. Demographic characteristics of pregnant women in the study by trimesters}

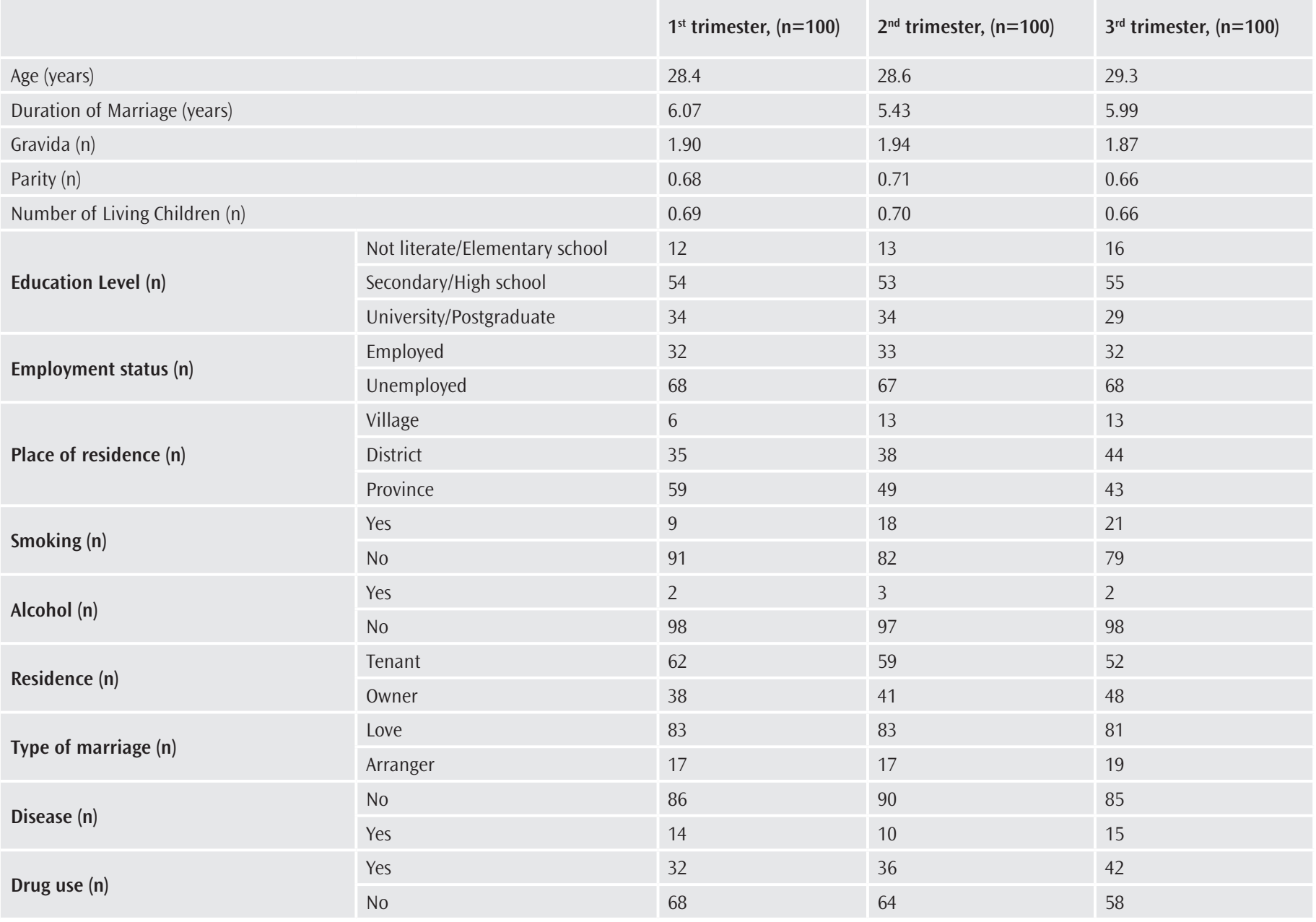


Considering whether previous birth histories of pregnant women included in the study had an effect on FSFI scores, only pain scores in the second trimester were significantly higher in multiparous women compared with nulliparous women $(p=0.009)$. Otherwise, there was no significant difference in the total median FSFI scores between three trimesters in multiparous and nulliparous women (Table 3).

The pregnant women were divided into 3 groups in terms of age $(<25$ years, 25-30, and $>30$ years). The effect of age on sexual functions was evaluated by using FSFI scores. The FSFI total median score in the first trimester group was 22.9 (20.5-24.7) in the $<25$ years group, 23.2 (19.6-
26.8) in the 25-30 years group and 22.8 (20.0-24.9) in the $>30$ years group. Similar calculations were made for other trimesters. There was no significant difference between the groups in terms of FSFI scores.

There was no significant difference between the education levels of the pregnant women and the FSFI and SQoL-F scores between the trimesters ( $p>0.05$ for all groups).

Considering the effect of parity on SQoL-F scale, median SQoL-F score in the nulliparous group before pregnancy was 68.8 (51.1-93.3) and 71.1 (51.1-91) in the multiparous group. There was no significant difference between the groups $(p=0.96)$. In pregnant women, SQoL-F score was

Table 2. Median FSFI subscale and SQoL-F scores by trimester

\begin{tabular}{|c|c|c|c|c|c|c|c|}
\hline & $1^{\text {st }}$ trimester $(\mathrm{T} 1)$ & $2^{\text {nd }}$ trimester $(\mathrm{T} 2)$ & $3^{\text {rd }}$ trimester $(\mathrm{T} 3)$ & p & p & p & p \\
\hline & Median, $(25-75 \%)$ & Median, (25-75\%) & Median, $(25-75 \%)$ & - & - & - & - \\
\hline SQOL-F & $55.5(44.4-80.0)$ & $64.4(52.2-88.8)$ & $64.9(57.7-92.2)$ & 0.003 & 0.005 & 0.02 & 0.63 \\
\hline \multicolumn{8}{|l|}{ FSFI } \\
\hline Desire & $3.6(3.0-4.8)$ & $3.6(3.0-4.8)$ & $3.6(2.4-4.8)$ & 0.51 & - & - & - \\
\hline Arousal & $3.9(2.8-4.8)$ & $4.2(3.0-4.8)$ & $4.0(1.9-4.8)$ & 0.56 & - & - & - \\
\hline Lubrication & $3.6(3.3-4.2)$ & $3.9(3.3-4.5)$ & $3.6(3.0-4.5)$ & 0.039 & 0.009 & 0.53 & 0.10 \\
\hline Orgasm & $4.0(3.2-4.4)$ & $4.0(3.6-4.8)$ & $3.6(2.4-4.4)$ & 0.76 & - & - & - \\
\hline Satisfaction & $4.0(3.2-4.8)$ & $4.8(3.8-5.2)$ & $4.2(2.4-5.2)$ & 0.012 & 0.014 & 0.62 & 0.08 \\
\hline Pain & $3.2(2.0-4.0)$ & $3.2(2.0-4.0)$ & $3.2(1.2-4.8)$ & 0.91 & - & - & - \\
\hline Total score & $22.8(20.0-25.1)$ & $23.6(21.7-26.1)$ & $22(16.1-25.5)$ & 0.048 & 0.13 & 0.24 & 0.018 \\
\hline
\end{tabular}

FSFI: female sexual function index, SQoL-F: sexual quality of life-female

Table 3. Effect of parity on FSFI score

\begin{tabular}{|c|c|c|c|c|}
\hline Trimester & & Nulliparous & Multiparous & p \\
\hline \multirow{8}{*}{$1^{\text {st }}$ trimester } & FSFI & Median, (\%25-75) & Median, (\%25-75) & - \\
\hline & Desire & $4.2(3.0-4.8)$ & $3.6(3.0-4.8)$ & 0.50 \\
\hline & Arousal & $3.9(2.7-4.8)$ & $3.6(2.8-4.6)$ & 0.92 \\
\hline & Satisfaction & $4.0(3.2-4.8)$ & $4.0(3.2-5.2)$ & 0.57 \\
\hline & Lubrication & $3.6(3.0-3.9)$ & $3.6(3.3-4.2)$ & 0.35 \\
\hline & Orgasm & $4.0(3.2-4.4)$ & $4.0(3.0-4.4)$ & 0.89 \\
\hline & Pain & $3.2(2.0-4.0)$ & $2.8(1.8-4.4)$ & 0.92 \\
\hline & Total & $22.8(19.6-25.1)$ & $22.9(20.1-25.1)$ & 0.83 \\
\hline \multirow{7}{*}{$2^{\text {nd }}$ trimester } & Desire & $3.6(3.3-4.8)$ & $3.6(3.0-4.5)$ & 0.43 \\
\hline & Arousal & $4.2(3.1-4.5)$ & $3.9(3.0-4.9)$ & 0.56 \\
\hline & Satisfaction & $4.8(4.0-5.2)$ & $4.8(3.6-5.2)$ & 0.68 \\
\hline & Lubrication & $3.9(3.3-4.5)$ & $4.0(3.6-4.8)$ & 0.35 \\
\hline & Orgasm & $4.0(3.4-4.6)$ & $4.2(3.6-4.8)$ & 0.26 \\
\hline & Pain & $2.8(1.8-3.6)$ & $3.6(2.4-4.6)$ & 0.009 \\
\hline & Total & $23.4(21.4-25.0)$ & $24.2(21.9-26.7)$ & 0.30 \\
\hline \multirow{7}{*}{$3^{\text {rd }}$ trimester } & Desire & $3.6(2.4-4.8)$ & $3.6(2.4-4.5)$ & 0.67 \\
\hline & Arousal & $3.6(1.5-4.8)$ & $3.8(2.1-4.5)$ & 0.91 \\
\hline & Satisfaction & $4.8(2.0-5.2)$ & $3.6(2.4-4.8)$ & 0.59 \\
\hline & Lubrication & $3.6(3.3-4.8)$ & $3.6(3.0-4.2)$ & 0.53 \\
\hline & Orgasm & $3.6(1.2-4.4)$ & $3.6(3.2-4.2)$ & 0.52 \\
\hline & Pain & $2.8(1.2-4.8)$ & $3.6(1.8-4.8)$ & 0.62 \\
\hline & Total & $22.6(16.0-25.7)$ & $21.0(16.3-25.2)$ & 0.77 \\
\hline
\end{tabular}




\begin{tabular}{|c|c|c|c|c|}
\hline & \multicolumn{2}{|c|}{$\begin{array}{l}\text { Before pregnancy, } \\
\text { SQoL-F }\end{array}$} & \multicolumn{2}{|c|}{$\begin{array}{l}\text { During pregnancy, } \\
\text { SQoL-F }\end{array}$} \\
\hline & r & $\mathrm{p}$ & $r$ & $\mathrm{p}$ \\
\hline $1^{\text {st }}$ trimester FSFI score & 0.064 & 0.52 & 0.22 & 0.03 \\
\hline $2^{\text {nd }}$ trimester FSFI score & 0.279 & 0.005 & 0.288 & 0.004 \\
\hline $3^{\text {rd }}$ trimester FSFI score & 0.242 & 0.015 & 0.268 & 0.007 \\
\hline
\end{tabular}

61.6 (48.8-90.0) in the nulliparous group and $63.3(50.0-87.7)$ in the multiparous group $(p=0.96)$.

There was no statistically significant difference between the first trimester FSFI score and SQoL-F score before pregnancy $(p=0.52)$. There was a significant difference between FSFI and SQoL-F in all other trimesters. However, the correlations were found to be low to moderate. The correlations between FSFI and SQoL-F in terms of the trimesters are given in Table 4.

\section{Discussion}

It is a known fact that pregnancy is effective on female sexual life. A decrease in sexual activity during pregnancy has been shown in studies (6,12-14). Physiological and psychological changes brought about by pregnancy may affect sexual function and satisfaction. In this respect, it is not surprising that in the literature, the studies on the sexual dysfunctions of pregnant women increase day by day. In these studies, correlations between sexuality related parameters and FSFI scores were investigated and data on sexual function changes in pregnancy were tried to be obtained.

The frequency of sexual activity among trimesters in pregnant women varies. The main reason for this is both hormonal and physiological changes due to pregnancy. Although the sexual activity level in the second trimester seems to be increasing compared to the other trimester, the frequency of sexual intercourse has generally decreased compared to non-pregnant individuals. Although in this study we obtained different data related to sexuality during pregnancy, we did not collect data about the frequency of sexual activity in pregnancy. However, studies on this subject reported that pregnant women avoid sexual activity during pregnancy $(6,15-17)$. It has been reported in studies that the incidence of sexual intercourse, with a mean of 3.2 per week before pregnancy, decreases to 1.8 per week with pregnancy (14). Similar results have been obtained in studies on SQoL during pregnancy and it has been shown that the SQoL has decreased during pregnancy. However, in studies conducted by Quirk et al. (18) and Maasoumi et al. (19), the mean scores of SQoL during pregnancy were higher compared to our study. We think that such a difference can be caused by social and racial diversities.

In this study, FSFI scores in the second trimester of pregnancy were found to be higher compared to the FSFI scores in the first and third trimesters of pregnancy. This finding is similar to the literature data $(6,12,14,16,17,20-22)$. It is known that although sexual function and related conditions vary in the second trimester and significantly decrease in the third trimester, it changes or decreases slightly in the first trimester $(13,21)$. In this study, we also found that FSFI scores in the third trimester were significantly decreased compared to other trimesters. Similarly, FSFI scores in first trimester were slightly higher than FSFI scores in the third trimester, but this was not statistically significant. The reason for the lack of statistical significance could be the low number of cases we included in the study.

In our study, we found that there were significant differences in the lubrication and satisfaction scores of the FSFI scores. Literature studies show that there are also differences between the trimesters in terms of desire, arousal and orgasm scores $(6,15,16)$. Although we found that lubrication, one of the sexual functions, was higher in the second trimester compared to the first trimester there are also studies indicating a decrease $(13,21)$. However, we think that the increase in lubrication in the second trimester is compatible with physiological and psychological changes during pregnancy.

One of the most important findings in our study is the increased sexual satisfaction FSFI score detected in the second trimester. When compared to other trimesters, the sexual satisfaction score was highest in the second trimester. This finding is also compatible with pregnancy physiology. Because this trimester is the period when the pregnant woman feels most comfortable. Sexual intercourse in this trimester will positively affect the pregnant woman both physiologically and psychologically. Therefore, the sexual satisfaction score will also be high in this trimester. Literature studies offer limited data especially for this subgroup. However, as previously mentioned, increased nausea and vomiting rates in the first trimester and infant awareness in the third trimester are among the most important causes of low satisfaction rates in the first and third trimesters (6). However, during pregnancy, both the partner and the pregnant have some concerns about pregnancy complications and these concerns may cause emotional changes among the couples.

It is known that the SQoL changes negatively as gestational week and number of births increase $(7,9)$. In our study, SQoL and FSFI scores fluctuated with increased gestational week. Second trimester scores were higher than first and third trimester scores. There was no decrease as the gestational week progressed but fluctuations were observed in the values. Again in our study, there was no statistically significant effect of the parity on FSFI scores. The reason for this is that the parity scores were evaluated as nulliparous and multiparous in our study. Therefore, our study is inadequate in evaluating the differences among the pregnant women who give more than one birth.

In the studies conducted, it was shown that the SQoL of pregnant women whose spouses are primary school graduates is lower when compared with pregnant women having spouses with high school graduates or higher education level $(1,3)$. In our study, we did not evaluate the education level of the spouses of pregnant women, we evaluated the relationship between the educational levels and sexual functions of pregnant women and found that the educational status of pregnant women had no effect on the SQoL or sexual functions. For this reason, we believe that it is appropriate to educate women about sex life and SQoL before and during pregnancy independently of their education level. 
Another result we found in this study is that the SQoL is highest in the second trimester. In the first trimester, the SQoL is the lowest. The first priority of the pregnant woman with the onset of pregnancy shifts from her spouse to her child, this causes temporary suppression of sexual desire and wishes in pregnant woman (21). The pregnant, who became sexually passive, suppresses these feelings with the sense that she will have a baby and cannot respond positively to her partner's sexual desires. Therefore, the decrease in the SQoL in pregnant women in the first trimester can be considered as a natural finding. With the transition to the second trimester, the pregnant woman is now accustomed to the pregnancy process, and her priority is directed back to her husband and naturally to her sexual life. In this period, in parallel with the increase in sexual function, the SQoL is affected positively, and the pregnant woman entered a period close to the psychological and physical wellbeing. However, as the time progresses, the diameter of the abdomen increases in parallel with the growth of the baby, and this starts to affect the SQoL negatively. For all these reasons, the changes in the SQoL that we found in our study are extremely natural.

In the literature, the number of studies related to SQoL in pregnancy is extremely limited. Studies have shown that the decrease in the SQoL is due to changes in sexual function observed in pregnancy (decrease in pleasure and decrease in satisfaction from sexuality) (23-25). However, in this study, we found a significant decrease in the SQoL in the first trimester and a higher quality of sexual life scores in the second trimester. These results, which we find partially different from the literature, can be affected by various factors such as differences in study designs, follow-up period of pregnant women and cultural differences.

It has been investigated in many different studies whether the parameters such as nulliparity or multiparity were effective on the SQoL. There are studies showing that the number of births decreases SQoL scores, and there are also studies showing that previous birth history is not effective in this respect $(7,8,10)$. Pregnant women who gave birth before gets faster through pregnancy psychology and this has a positive effect on sexual life in their subsequent pregnancies. The pregnant woman who gets rid of emotional period early in the first trimester becomes more active and willing in terms of sexual life. Although we found that having a child before had a positive effect on the SQoL in our study, this was not statistically significant.

\section{Conclusion}

As a result, social and cultural factors significantly affect the sexual life of couples during pregnancy. In particular, the education levels of couples, employment status, marriage period and even their ethnic identity can affect the sexual functions during pregnancy. However, nausea and vomiting, fatigue and feeling of tiredness that are frequently observed during pregnancy are other factors that negatively affect sexuality in pregnant women. Although there are differences in sexual desire in the first trimester of pregnancy, the general opinion is that there is a decrease in sexual function due to the decrease of libido. The woman's belly begins to grow as the pregnancy progresses, and she starts to experience difficulties in sex positions. This is the most common cause of sexual dysfunction observed in the third trimester.
Considering that sexuality is an important part of health care, we believe that the problems related to sexual dysfunctions of pregnant women should be detected and resolved at an early stage, and that this will help to improve the sexual health of the pregnant woman and her partner and their SQoL.

Ethics Committee Approval: This study was performed in accordance with the Declaration of Helsinki and Çanakkale Onsekiz Mart University Clinical Research Ethics Committee approved this study (decision no: 2017-11, date: 07.06.2017).

Informed Consent: Written consent was obtained.

Peer-review: External and internal peer-reviewed.

Author Contributions: Concept - E.C.., F.B.; Design - E.Ç.; Supervision - F.B.; Resources - E.C.., F.B.; Materials - E.C..; Data Collection and/or Processing - E.C..; Analysis and/or Interpretation E.C.., F.B.; Literature Search - E.Ç.; Writing Manuscript - E.C..; Critical Review - F.B.

Conflict of Interest: No conflict of interest was declared by the authors.

Financial Disclosure: The author declared that this study has received no financial support.

\section{References}

1. Leonardi-Warren K, Neff I, Mancuso M, Wenger B, Galbraith M, Fink R. Sexual health: exploring patient needs and healthcare provider comfort and knowledge. Clin J Oncol Nurs 2016; 20: 162-7.

2. Kisa S, Zeyneloğlu S, Yilmaz D, Güner T. Quality of sexual life and its effect on marital adjustment of Turkish women in pregnancy. J Sex Marital Ther 2014; 40: 309-22.

3. Andreucci CB, Bussadori JC, Pacagnella RC, Chou D, Filippi V, Say L, et al. Sexual life and dysfunction after maternal morbidity: a systematic review. BMC Pregnancy Childbirth 2015; 15: 307.

4. Bretschneider CE, Doll KM, Bensen JT, Gehrig PA, Wu JM, Geller EJ. Sexual health before treatment in women with suspected gynecologic malignancy. J Womens Health (Larchmt) 2017; 26: 1326-32.

5. Tuğut N, Gölbașı Z. A validity and reliability study of Turkish version of the sexual quality of life questionnaire-female. Cumhuriyet Med J 2010; 32: 172 80 .

6. von Sydow K. Sexuality during pregnancy and after childbirth: a metacontent analysis of 59 studies. J Psychosom Res 1999; 47: 27-49.

7. Leite AP, Campos AA, Dias AR, Amed AM, De Souza E, Camano L. Prevalence of sexual dysfunction during pregnancy. Rev Assoc Med Bras (1992) 2009; 55 : 563-8.

8. Kingsberg S, Althof SE. Evaluation and treatment of female sexual disorders. Int Urogynecol J Pelvic Floor Dysfunct 2009; 20(Suppl 1): 33-43.

9. Moodley J, Khedun M. Sexual activity during pregnancy: a questionnairebased study. Southern african journal of epidemiology and infection 2011; 26: 33-5.

10. Rosen R, Brown C, Heiman J, Leiblum S, Meston C, Shabsigh R, et al. The female sexual function index (FSFI): A multidimensional selfreport instrument for the assessment of female sexual function. J Sex Marital Ther 2000; 26: 191-208.

11. Aygin D, Eti Aslan F. Kadın cinsel ișlev ölçeğinin Türkçe'ye uyarlanması. Türkiye Klinikleri J Med Sci 2005; 25:393-9. 
12. Bartellas E, Crane JM, Daley M, Bennett KA, Hutchens D. Sexuality and sexual activity in pregnancy. BJOG 2000; 107: 1306-8.

13. Lee JT. The meaning of sexual satisfaction in pregnant Taiwanese women. J Midwifery Womens Health 2002; 47: 278-86.

14. Onah HE, Iloabachie GC, Obi SN, Ezugwu FO, Eze JN. Nigerian male sexual activity during pregnancy. Int J Gynaecol Obstet 2002; 76: 219-23.

15. Perkins RP. Sexuality in pregnancy: what determines behavior? Obstet Gynecol 1982; 59: 189-98.

16. de Pierrepont C, Polomeno V, Bouchard L, Reissing E. (What do we know about perinatal sexuality? A scoping reviewon sexoperinatality-part 1). J Gynecol Obstet Biol Reprod (Paris) 2016; 45: 796-808.

17. Jones C, Chan C, Farine D. Sex in pregnancy. CMAJ 2011; 183: 815-8.

18. Quirk F, Haughie S, Symonds T. The use of the sexual function questionnaire as a screening toolfor women with sexual dysfunction. J Sex Med 2005; 2: 469-77.
19. Maasoumi R, Lamyian M, Montazeri A, Azin SA, Aguilar-Vafaie ME, Hajizadeh E. The sexual quality of life-female (SQOL-F) questionnaire: translation and psychometric properties of the Iranian version. Reprod Health 2013; 10: 25.

20. Orji EO, Ogunlola IO, Fasubaa OB. Sexuality among pregnant women in South West Nigeria. J Obstet Gynaecol 2002; 22: 166-8.

21. Oruç S, Esen A, Laçin S, Adigüzel H, Uyar Y, Koyuncu F. Sexual behaviour during pregnancy. Aust N Z J Obstet Gynaecol 1999; 39: 48-50.

22. Ryding EL. Sexuality during and after pregnancy. Acta Obstet Gynecol Scand 1984; 63: 679-82.

23. Fok WY, Chan LY, Yuen PM. Sexual behavior and activity in Chinese pregnant women. Acta Obstet Gynecol Scand 2005; 84: 934-8.

24. Bartellas E, Crane JM, Daley M, Bennett KA, Hutchens D. Sexuality and sexual activity in pregnancy. BJOG 2000; 107: 964-8.

25. Johnson CE. Sexual health during pregnancy and the postpartum. J Sex Med 2011; 8: 1267-84. 